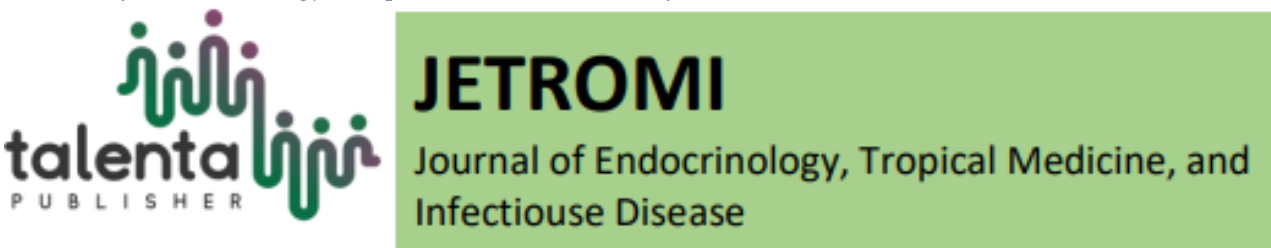

\title{
PERIOPERATIVE MANAGEMENT IN PATIENTS WITH LONG-TERM STEROID USE
}

\author{
Agustia Sukri Ekadamayanti ${ }^{1}$, Hendra Zufry ${ }^{1}$, Krishna W Sucipto ${ }^{1}$ \\ ${ }^{1}$ Division of Endocrinology, Metabolism and Diabetes, Department of Internal Medicine, Universitas \\ Syiah Kuala School of Medicine-dr.Zainoel Abidin General Teaching Hospital, Banda Aceh, Indonesia
}

\begin{abstract}
Systemic corticosteroid given with oral or parenteral route is widely used in the treatment of various condition and has potent anti-inflammatory, imunomodulatory, and anti-neoplastic effect. Although steroid has potentially clinical benefit effects, long-term use of this regiment also associated with several serious risks and may deteriorate life quality and high cost management. Long-term steroid use may alter our body response to stress due to HPA Axis suppression. Surgical procedure will increase stress in our body, which can lead into higher demand of cortisol. When surgery performed, a signal from the operation site through afferent nerve will activate hypothalamus to release corticotropin releasing hormone, that will stimulate cortisol hypersecretion. Preoperative management guidelines recommend the use of stress dose or supplementation dose for patient with longterm steroid use, which will be discussed further in this review article with additional case illustration.
\end{abstract}

Keyword: Corticosteroids, HPA Axis, Surgery

\begin{abstract}
Abstrak. Kortikosteroid sistemik yang diberikan dengan rute oral atau parenteral banyak digunakan dalam pengobatan berbagai kondisi dan memiliki efek antiinflamasi, imunomodulator, dan anti neoplastik yang kuat. Meskipun steroid berpotensi memiliki efek manfaat klinis, penggunaan jangka panjang resimen ini juga dikaitkan dengan beberapa risiko serius dan dapat menurunkan kualitas hidup dan manajemen biaya tinggi. Penggunaan steroid jangka panjang dapat mengubah respons tubuh kita terhadap stres karena penekanan HPA Axis. Prosedur bedah akan meningkatkan stres di tubuh kita, yang dapat menyebabkan permintaan kortisol yang lebih tinggi. Ketika operasi dilakukan, sinyal dari tempat operasi melalui afferent nervus akan mengaktifkan hipotalamus untuk melepaskan hormon pelepas kortikotropin, yang akan merangsang sekresi hiper kortisol. Pedoman manajemen pra operasi merekomendasikan penggunaan dosis stres atau dosis suplemen untuk pasien dengan penggunaan steroid jangka panjang, yang akan dibahas lebih lanjut dalam tinjauan pustaka ini beserta ilustrasi kasus.
\end{abstract}

Kata Kunci: Kortikosteroid, aksis-HPA, Operasi

Received 11 October 2019 | Revised 18 November 2019| Accepted 25 November 2019

\footnotetext{
*Corresponding author at: Division of Endocrinology, Metabolism and Diabetes, Department of Internal Medicine, Universitas Syiah Kuala School of Medicine- dr.Zainoel Abidin General Teaching Hospital, Banda Aceh, Indonesia
} 


\section{Introduction}

Systemic corticosteroid given with oral or parenteral route, for examples prednisone, prednisolone, methyl prednisolone and dexamethasone has potent anti-inflammatory, imunomodulatory, and anti-neoplastic effect and is widely use in the treatment of various condition, including autoimmune diseases, allergic reactions, asthma exacerbation, chronic pulmonary obstructive disease also malignancies. Although steroid has potentially clinical benefit effects, long-term use of these regiment also associated with several serious risk like osteoporosis, cardiovascular disease, impaired immune response and prolong wound healing, alteration of lipid and glucose metabolism and psychiatric disturbance. Such complications may deteriorate life quality and highly cost management.[1] Surgical procedure will increase stress in our body, which can led into higher demand of cortisol. When surgery performed, a signal from the operation site through afferent nervus will activate hypothalamus to release corticotropin releasing hormone, that will stimulate cortisol hypersecretion.[2,3]

Long-term use of steroid will decrease cortisol respond to stress and dose duration use of glucocorticoid has correlation with adrenal suppression.[4] We will reperesent a case of a woman with long term steroid use that will undergo surgery.

\section{Case Ilustration}

A 38 years old female patient, Mrs.RZ, has been diagnosed with pemphigus vulgasris since 2011 and has been treated with corticosteroid. The dose has been reduced from $125 \mathrm{mg} /$ day prednisone to $64 \mathrm{mg} / \mathrm{day}$ methylprednisolone, and now she routinely consume $8 \mathrm{mg}$ methyl prednisolone 3 times a week for more than 3 month. She was also diagnosed with myoma utery and was planned to have total hysterectomy, the obstetry and gynecology department consult to endocrinology division for pre-operative management due to prolong steroid use.

The vital sign are within normal limits. We found moon face, but there was no buffalo hump and red striae on her abdomen. Her cardio and pulmonary physical examination was normal. There was palpable lump in her abdomen. On laboratory examination we found normal routine blood, electrolyte, blood glucose and kidney function measurements.

How does the perioperative management of this patient with long-term steroid use in endocrinology point of view?

\section{Discussion}

Secretion and synthesis of glucocorticoid (cortisol) hormones by the adrenal cortex are predominantly affected by adrenocorticotropic hormone (ACTH) secreted by the anterior pituitary under the influence of the corticotropin-releasing hormone $(\mathrm{CRH})$ produced in the 
hypothalamus. ACTH and CRH regulate cortisol secretion through a negative feedback mechanism.[5] The normal production of cortisol is in the range of 15-20 mg per day.[6]

The main functions of cortisol are: 1) Control the metabolism of carbohydrate proteins and fats; 2) Suppression of inflammatory tissue processes in response to injury; 3) Suppression of immune responses to foreign antigens; 4) Increase the body's ability to withstand various stimuli that endanger (stress).[7]

Steroid use may cause iatrogenic Adrenal Insufficiency (AI) which caused by suppression of the HPA axis due to the use of glucocorticoids at therapeutic doses. Degree of HPA axis suppression and adrenal atrophy in patients receiving exogenous glucocorticoids is related to the duration and dosage of the drug. However, several studies have shown a low correlation between HPA axis function and cumulative dose, the largest dose or duration of therapy. Because of the considerable inter-individual variability in the degree and duration of adrenal suppression, it is difficult to accurately predict which patients will develop into AI when glucocorticoid treatment is stopped. Several case reports that have been published regarding steroid induced adrenal insufficiency do not provide sufficient information to be used as a reference for clinical diagnosis of HPA axis suppression and the risk of AI. They were unable to determine the duration of steroid therapy use that will make adrenal suppression become overt, how much the dose could cause adrenal suppression and how long does it take for HPA Axis recovery after the cessation of glucocorticoids.[8] However, it is simply believed that for patients taking steroids at any dose less than 3 weeks, the suppression of the HPA axis is not clinically significant. Conversely, patients taking steroid doses which are equivalent to prednisolone $15 \mathrm{mg} /$ day for more than three weeks should be suspected for having the HPA axis suppression.[9]

Hormonal responses to surgery, critical condition, and trauma have been widely studied over the past 20 years. Plasma ACTH, plasma cortisol concentrations, free cortisol urine, and urinary cortisol concentrations increases in response to surgery, trauma, and other forms of critical illness.[10] Surgery is a stressor that can be categorized base on duration and severity level and may induce a systemic response for stress which includes an increase in adrenal cortisol production.[3]

When stress occurs and the hypothalamus is stimulated, CRH is released. CRH then stimulates ACTH release from the anterior pituitary, that will cause an increase in glucocorticoid synthesis in the adrenal cortex. In surgery, the main mechanism responsible for cortisol hypersecretion as response to stress is preceded by afferent nerve signals obtained from the surgical site which then stimulates the hypothalamus to release the corticotropin hormone and arginine vasopressin. These two peptides then stimulate the secretion of the adenocorticotropic hormone from the anterior pituitary, which stimulates cortisol secretion by the adrenal cortex.[2] 
Under normal conditions, the adrenal glands from healthy adults produces cortisol as much as $10-20 \mathrm{mg} /$ day and in a stress full state, cortisol hormone secretion will increase around 150 $\mathrm{mg} /$ day.[11] Then in a state of long-term steroid use, adrenal suppression or HPA Axis suppression may occur, hence the natural response of endogenous cortisol to stress cannot achieved resulting in adrenal insufficiency.

\section{Preoperative Management in Patients with Long-term Steroid Use}

Surgery make's our body to be in a state of stress, thus requiring greater cortisol. The use of corticosteroids at a dose of 20-30 mg of prednisone per day for more than 1 week should be suspected of having adrenal or HPA Axis suppression. Thus the preoperative guidelines recommends steroid supplementation for preoperative patients. Guidelines by Salem, et al. [10], requirement of preoperative steroid supplementation in patients with long-term steroid use in minor, moderate or major surgery which dose adjusted based on the type of surgery and estimated steroid dose requirements based on the stress arising from surgery. However, a study conducted by Groleau et al. [12] which objective is to the determine whether the administration of perioperative corticosteroids, compared with placebo or without intervention, reduces the incidence of adrenal insufficiency in adult patients exposed to corticosteroids and undergo noncardiac surgery. The results of the study found that corticosteroid stress-dose in perioperative therapy may not be needed as an addition to the patient's daily steroid dose and the patient's daily steroid dose is sufficient in some cases. This review concludes that the current widespread practice of providing supra-physiological corticosteroid supplementation in perioperative management of patient who have used steroids before, was not supported by sufficient literature. In another study conducted by Prete et al. [3] found that the cortisol response was significantly different between patients undergoing minimally invasive (grade I) surgery compared to patients undergoing moderate and high invasive surgery (grade II and III). Interestingly, grade I surgery did not cause an increase in peri-operative cortisol. In grade II and III operations there was no significant differences cortisol elevation level during extubation and 18 hours after surgery. And that increase in cortisol lasts until 1 week after surgery.

The existing perioperative guidelines divide the condition of patients using steroids into 3 categories; the very unlikely group, the intermediate group or the unknown group and the very likely group experienced HPA Axis suppression. Patients who are very unlikely to have HPA axis suppression are a group of patients receiving glucocorticoid therapy with dose of $5 \mathrm{mg} /$ day or less prednisone or equivalent, or getting steroid therapy for less than 3 weeks. Patients in this group has low risk and may continue the usual daily dose and do not requiring steroid supplementation or stress doses steroid. Patients in this group also do not need a supportive examination to assess adrenal function, unless the results of the examination can change their perioperative management. Blood pressure monitoring alone is sufficient. Patients who are 
known to have HPA axis suppression or have a high risk are patients receiving glucocorticoids at a dose of $20 \mathrm{mg} /$ day or more prednisone or equivalent for more than 3 weeks, or the group receiving glucocorticoid therapy due to primary adrenal insufficiency or cushing syndromes which is clearly considered to have a high risk suppression of the HPA axis. This group must have preoperative steroid supplementation. Patients in the intermediate group or unknown risk of HPA axis suppression were not included in the low or high risk categories as previously mentioned. This group is patients that is being or have received prednisone therapy at a dose of $5-20 \mathrm{mg} /$ day or equivalent for more than 3 weeks in the past year. Patients in this group tend to have wide variations in HPA axis suppression and need to undergo an examination to assess the HPA axis.[13]

When preoperative evaluation is needed, a short ACTH stimulation test is an option for assessing the integrity and function of the HPA axis. This test is done by giving $250 \mu \mathrm{g}$ cortrosyn in the morning after the patient overnight fast and blood samples is taken to be tested for baseline ACTH and cortisol. At minute 30 and 60 after the injection, the sample was taken again for cortisol examination. If the response is normal (increase $\geq 18 \mu \mathrm{g} / \mathrm{dL}$ ), then no further evaluation is required, nor the dose of steroid supplementation/stress dose steroid. Other tests that can be done are the insulin-induced hypoglycaemia or low-dose ACTH $(1 \mu \mathrm{g})$ examination, but this methode is more difficult and with high risk, so the cortrosyn test is an option to do, although this examination also has limitations. Because this examination only assessed total serum cortisol levels rather than serum free cortisol which plays a role in the physiological effects of cortisol.[14]

The recommended stress dose or supplementation dose of steroid were based on type of surgery; superficial surgery (ex. dental surgery or biopsy) use the usual daily dose. Minor surgery (ex. Inguinal hernia repair, colonoscopy, uterine curettage, hand surgery), and moderate surgery (ex. total joint replacement, colon resection) use the daily dose plus hydrocortisone $50 \mathrm{mg}$ IV before incision continue with hydrocortisone $25 \mathrm{mg}$ IV every 8 hour x 24 hour, then usual daily dose. for major surgery (ex. major cardiac/vascular) use usual daily dose plus hydrocortisone $100 \mathrm{mg}$ before incision followed by continuous IV infusion of $200 \mathrm{mg}$ hydrocortisone more than 24 hour or hydrocortisone $50 \mathrm{mg}$ IV every $8 \mathrm{~h} \mathrm{x} 24 \mathrm{~h}$ taper dose by half per day until usual daily dose reached plus continuous IV fluids with 5\% dextrose and 0,2-0,45\% $\mathrm{NaCl}$ (Based on degree of hypoglycaemia).[14]

\section{Conclusion}

Long-term steroid use may result in iatrogenic adrenal insufficiency, due to HPA-Axis supression 
Stress due to surgical procedure may increase the need of cortisol, which in long-term steroid use patients cannot be secreted due to adrenal insufficiency

Patient in case illustration is recommended to continue her preoperative steroid dose as usual and continued until postoperative periode. It's not recommended to add stress dose or supplementation dose, since this patient daily steroid dose does not exceed $10 \mathrm{mg} / \mathrm{day}$ prednisone or equivalent or with low risk category. No need to measure HPA Axis, since this patient use low dose steroid for more than 3 weeks. We need to monitor postoperative hemodynamic if hypotension and symptoms of acute adrenal insufficiency occur, steroid supplementation can be given as therapy. 


\section{REFERENCE}

[1] B.J. Rice, A.G. White, L.M Scarpati, G. Wan, \& W.W. Nelson, "Long-term systemic corticosteroid exposure: A systematic literature review", Clinical Therapeutics, vol. 39, no.11, pp. 2216-2229. 2017.

[2] K.N. Kelly and B. Domajnko, "Perioperative stress-dose steroids", Clin Colon Rectal Surg, vol.26. no.3, pp.163-167. 2013.

[3] A. Prete, Q. Yan, \& K. Al-Tarrah, et al, "The cortisol stress response induced by surgery : A systematic review and meta-analysis", Clinical Endocrinology, vol. 89, pp. 554-567. 2018.

[4] N. Gibson and J.W. Ferguson, "Steroid cover for dental patients on long-term steroid medication:proposed clinical guidelines based upon a critical review of the literature", British Dental Journal, vol.197, pp. 681-685. 2014.

[5] S.A. Jabbour, "Steroids and the surgical patient", Medical Clinics of North America, vol.85, pp. 1311-1317. 2001.

[6] P.M. Stewart and J.D.C. Newell-Price, The Adrenal Cortex, In : Melmed S, Polonsky KS, Larsen PR, Kronenberg HM (Eds.), Williams Textbook of Endocrinology, 13th ed., Elsevier, Philadelphia, p.490, 2016.

[7] A. Shahab, Kelenjar Adrenal, In :Shahab S, Windarti S (Eds.), Dasar-Dasar Endokrinologi, Rayyana Komunikasindo, Jakarta, p.45, 2017.

[8] L. Axelrod, "Perioperative management of patients treated with glucocorticoids", Endocrinol Metab Clin N Am, vol.32, pp. 367-383. 2003.

[9] C. Jung and W.J. Inder, "Management of Adrenal Insufficiency during the stress of medical illness and surgery", MJA, vol.188, pp. 409-413, 2008.

[10] M. Salem, R.E. Tainsh, J. Bromberg, D.L Loriaux \& B. Chernow, "Perioperative Glucocorticoid coverage A reassessment 42 years after emergence of a problem", Annals of Surgery, vol.219, pp.416-425, 1994.

[11] J.H Wakim and K.C Sledge, "Anesthetic implications for patients receiving exogenous corticosteroids", AANA Journal, vol.74, pp.133-139, 2006.

[12] C. Groleau. S.N. Morin, L. Vautour, A. Amar-Zifkin \& A. Bessissow, Perioperative corticosteroids administration : A systematic review and descriptive analysis, Perioperative Medicine, vol.7. pp.1-8, 2018. 
[13] L. Freudzon, Perioperative steroid therapy: Where's the evidence?, Curr Opin Anesthesiol, vol.30. pp. 1-4, 2017.

[14] M.M Liu, A.B Reidy, S. Saatee \& C.D. Collard, Perioperative Steroid Management, Anesthesiology, vol 127, pp. 166-172, 2017. 